\title{
A SIMPLIFIED METHOD TO PREDICT PEAK VALUE AND TREND OF SEISMIC RELATIVE MOTION BETWEEN ADJACENT BUILDINGS
}

\author{
地震時における隣接建物間の相対変位の最大值やその傾向の簡易予測法 \\ Kazuhiko KASAI* and Binh T. TRAN** \\ 笠井和彦, チャン タン ビン
}

\begin{abstract}
Seismic pounding of two closely-spaced buildings can be a serious hazard, and adequate building separation distance must be used to preclude pounding. It can be calculated as the peak value of the relative displacement between the buildings through time history analysis. For an alternative and more practical estimate, the writers proposed the "spectral difference (SPD) rule" that simply uses the buildings' peak displacements. The present paper proposes a simplified method combining the rule with elastic response spectrum to approximate peak inelastic displacement of each building. Utilizing this SPD-based method, the paper clarifies the relative displacement trends based on building periods, damping ratios, ductility demands, and earthquake spectral characteristics. The method is validated and various trends discussed by using numerous code-compatible building pairs and 33 earthquakes. The SPD-based method is shown to be much more accurate than other simplified methods, due to its ability to account for the inelastic vibration phase of two buildings. The results are also readily applicable to the problem of finding a necessary sliding seat distance to prevent falling of a bridge, which is supported by two separate structures developing relative motion.
\end{abstract}

Keywords: adjacent inelastic structures, relative displacement, required separation, inelastic vibration phase, spectral difference $(S P D)$ rule, response spectrum.

隣接弹塑性構造, 相対変位, 建物要求間隔, 弾塑性振動位相, スペクトル差法, 応答スペクトル

\section{INTRODUCTION}

\subsection{Relative Displacement Problem}

In recent years, there has been increased awareness of the potential impact of buildings during moderate to strong earthquakes due to insufficient separation distance ${ }^{1)-3}$. Pounding can occur between the two buildings adjacent to each other, or between the segments of a building connected via an expansion joint or a bridge component.

Magnitude of adequate building separation distance $s$ (Fig. 1) can be estimated by calculating the buildings' peak relative displacement through time history analysis. However, since one cannot determine specifically the future earthquake time history, a spectrum approach that uses an ensemble from the past and potential earthquakes would be more reliable and preferred. It also has an advantage of ease of use over the time history approach.

The peak relative displacement between the two buildings depends not
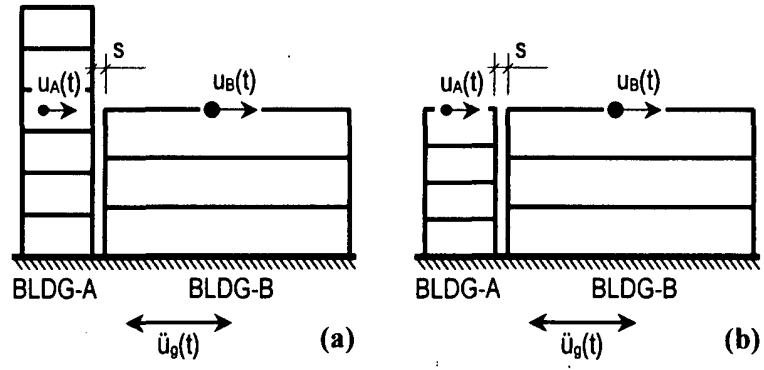

Figure 1. Relative Displacement of Adjacent Buildings. only on the peak displacement of each separate building, but also on the "vibration phase" associated with their elastic and inelastic responses. Therefore, the effects from key parameters such as adjacent buildings' vibration periods, damping ratios, heights, ductility demands, and even hysteretic types must be considered in order to understand the relative displacement problem. Obviously, time history approach is not appropriate for such a task.

\subsection{Objectives and Scopes}

Kasai et al. ${ }^{4), 5)}$ presented a method called "spectral difference (SPD) rule" using response spectrum to estimate the maximum relative displacement. The method provides a closed-form solution that relates those key parameters with the buildings' relative motion. Nevertheless, using directly this SPD rule requires either inelastic response spectrum or time history analysis to obtain peak inelastic displacement of each separate building.

The objective of this paper, therefore, is to propose a practical SPD-based method by implementing more simplifications. The proposed method employs only elastic response spectrum to approximate peak inelastic displacement of each structure.

Validation study is conducted considering various adjacent building pairs having stiffness and strength consistent with the Japanese seismic code and an ensemble of 33 earthquakes scaled to different levels. For each case, the peak relative displacement is estimated using the SPD-based method and others. Time history analysis is also used to obtain an 'exact' solution. The accuracy of the SPD-based method will
* Prof., Struct. Eng. Research Center, Tokyo Institute of Technology, Ph. D.

** Graduate Student, Dept. of Built Environment, Tokyo Institute of Technology
東京工鄴大学建築物理研究センター 教授・Ph.D. 東京工業大学人間環境システム専攻 大学院生 
be exemplified by comparing with other methods.

Furthermore, the trend of the peak relative displacement will be clarified by explaining the complex effect of the above-mentioned key factors through the SPD-based method. Unlike the previous studies, this work aims to emphasize on the significant effect of yielding on buildings' phase motion and relative displacement. The study would be useful for understanding and controlling the relative displacement.

The results are also readily applicable to the problem of finding a necessary sliding seat distance to prevent falling of a bridge, which is supported by two separate structures developing relative motion.

\section{RRLATIVE DISPLACEMENT AND VARIOUS ESTIMATES \\ 8.1 Past $\mathbb{R}$ anles}

From Fig. 1, the relative displacement $u_{\text {rel }}(t)$ between buildings $\mathrm{A}$ and $\mathrm{B}$ is expressed as

$$
u_{\mathrm{rel}}(t)=u_{\mathrm{A}}(t)-u_{\mathrm{B}}(t)
$$

where $u_{\mathrm{A}}(t), u_{\mathrm{B}}(t)=$ displacement time histories at potential pounding locations. From now on, the subscripts " $A$ " and " $B$ " shall refer to buildings $A$ and $B$, respectively.

Peak relative displacement between the buildings is determined as

$$
u_{\mathrm{rel}}(\mathrm{TH})=\max \left[u_{\mathrm{rel}}(t)\right] \quad(>0)
$$

' $\mathrm{TH}$ ' indicates results from time history analysis, and pounding is avoided if the separation distance $s>u_{\text {rel }}(\mathrm{TH})$. Note that one needs to consider both directions of earthquake, it is equivalent to utilize a single direction earthquake and additionally consider $u_{\mathrm{B}}(t)-u_{\mathrm{A}}(t)$ in Eqs. 1,2.

Two other methods for estimating the peak relative displacement are the absolute-sum (ABS) rule and the square-root-of-sum-of-squares (SRSS) rule such as

$$
u_{\mathrm{rel}}(\mathrm{ABS})=u_{\mathrm{A}}+u_{\mathrm{B}}, u_{\mathrm{rel}}(\mathrm{SRSS})=\sqrt{u_{\mathrm{A}}^{2}+u_{\mathrm{B}}^{2}}
$$

where $u_{\mathrm{A}}, u_{\mathrm{B}}=$ the absolute peak displacements of the buildings, which can be obtained from the response spectrum. The use of the SRSS rule is stipulated in the U.S. seismic code ${ }^{6}$.

\subsection{Spectral Difference (SPD) $\mathbb{R}$ unle}

Unlike the ABS and SRSS rules, the SPD rule uses a cross correlation coefficient $\rho_{\mathrm{AB}}$ and provides average estimate also for both directions of earthquake as just mentioned above.

$$
u_{\text {rel }}(\mathrm{SPD})=\sqrt{u_{\mathrm{A}}^{2}+u_{\mathrm{B}}^{2}-2 \rho_{\mathrm{AB}} u_{\mathrm{A}} u_{\mathrm{B}}}
$$

Especially when Eq. 4 gives very small $u_{\text {rel, }}$, although theoretically valid, Ref. 4 provided a lower bound of its value for a practical and conservative reason. In the present paper, however, such a consideration is omitted in order to clarify the accuracy of the present concept.

The $\rho_{\mathrm{AB}}$ reflects vibration phase of buildings $\mathrm{A}$ and $\mathrm{B}$, and it was derived from a random vibration theory as follows ${ }^{5), 7}$ ):

$$
\rho_{\mathrm{AB}}=\frac{8 \sqrt{\xi_{\mathrm{A}}^{*} \xi_{\mathrm{B}}^{*}}\left(\xi_{\mathrm{B}}^{*}+\beta^{*} \xi_{\mathrm{A}}^{*}\right) \beta^{* 1.5}}{\left(1-\beta^{* 2}\right)^{2}+4 \xi_{\mathrm{A}}^{\circ} \xi_{\mathrm{B}}^{*}\left(1+\beta^{* 2}\right) \beta^{\circ}+4\left(\xi_{\mathrm{B}}^{\circ 2}+\xi_{\mathrm{A}}^{* 2}\right) \beta^{* 2}}
$$

where $\beta^{*}=$ ratio of effective vibration periods $T_{\mathrm{B}}^{*} / T_{\mathrm{A}}^{*}, \xi_{\mathrm{A}}^{*}$ and $\xi_{\mathrm{B}}^{*}=$ effective damping ratios. Note that $0 \leq \rho_{A B} \leq 1$, and larger $\rho_{A B}$ means more in-phase motion, and consequently smaller $u_{\text {rel }}$ (Eq. 4).

Eq. 5 explains that $T^{p}$ and $\xi^{\alpha}$ play a key role in vibration phase. When $T_{\mathrm{B}}^{*} / T_{\mathrm{A}}^{*}$ is close to 1 , and/or $\xi_{\mathrm{A}}^{*}$ and $\xi_{\mathrm{B}}^{*}$ are large, $\rho_{\mathrm{AB}}$ approaches 1 , and in-phase motion develops. Inclusion of damping comes from the fact that damping tends to eliminate a free vibration portion of the seismic response, and mainly a forced vibration portion remains, making the two buildings vibrate similarly to the ground motion ${ }^{4), 8)}$.
From Ref. 4 , for the buildings with bilinear hysteresis (Fig. 2a) and stiffness degrading hysteresis (Fig. 2b), the above effective properties for $\mu$ up to 6 are given as:

Bilinear: $\quad T^{\circ}=T[1+0.09(\mu-1)] \quad ; \quad \xi^{\circ}=\xi+0.084(\mu-1)^{1.3}$

Degrading: $T^{\circ}=T[1+0.18(\mu-1)] ; \xi^{\circ}=\xi+0.16(\mu-1)^{0.9}$

where $T, \xi, \mu=$ initial elastic vibration period, initial viscous damping ratio, and peak ductility demand, respectively. Note that these effective period and damping differ from those used in predicting peak displacement of a single inelastic structure. Besides, effect of residual displacement (one-sided movement) was already statistically accounted for in Eqs. 6 via consideration of both directions of many earthquakes ${ }^{4)}$.
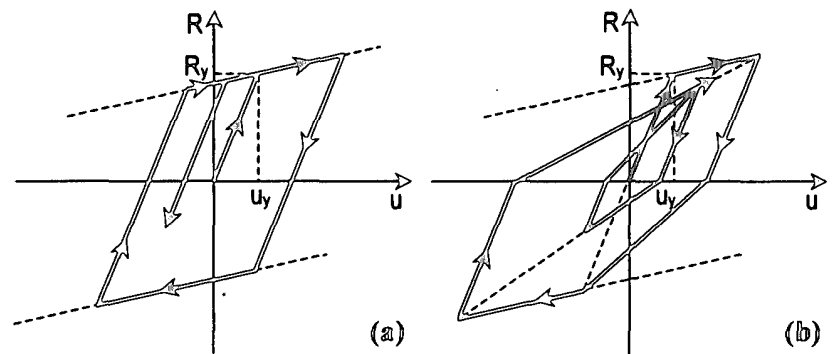

Figure 2. Hysteretic Behavior: (a) Bilimear $\mathbb{B}$ unildimg Model, and (b) Stiffiness $\mathbb{D}$ egradimg Model.

\section{TRRENDS OF RELATIVE MOTION AND PHASE}

Kasai et al. ${ }^{4)}$ discussed the trends of $\rho_{\mathrm{AB}}$ and $u_{\text {rel }}$ for adjacent inelastic buildings having the same ductility demand $\mu$. In this chapter, a more general case of different $\mu$ 's will be investigated.

\subsection{Tremds of Relative Mation}

Consider two single-degree-of-freedom (SDOF) systems A and B with initial vibration periods $T_{\mathrm{A}}$ and $T_{\mathrm{B}}=1.0 \mathrm{~s}, 1.3 \mathrm{~s}$, and initial viscous damping ratios $\xi_{\mathrm{A}}=\xi_{\mathrm{B}}=0.02$. The stiffness degrading hysteretic model (Fig. 2b) is used with strain-hardening ratio $5 \%$. The systems are designed under the three cases described below, and they are subjected to the 1940 Imperial Valley earthquake (117 El Centro station, $0.35 \mathrm{~g}$ ).
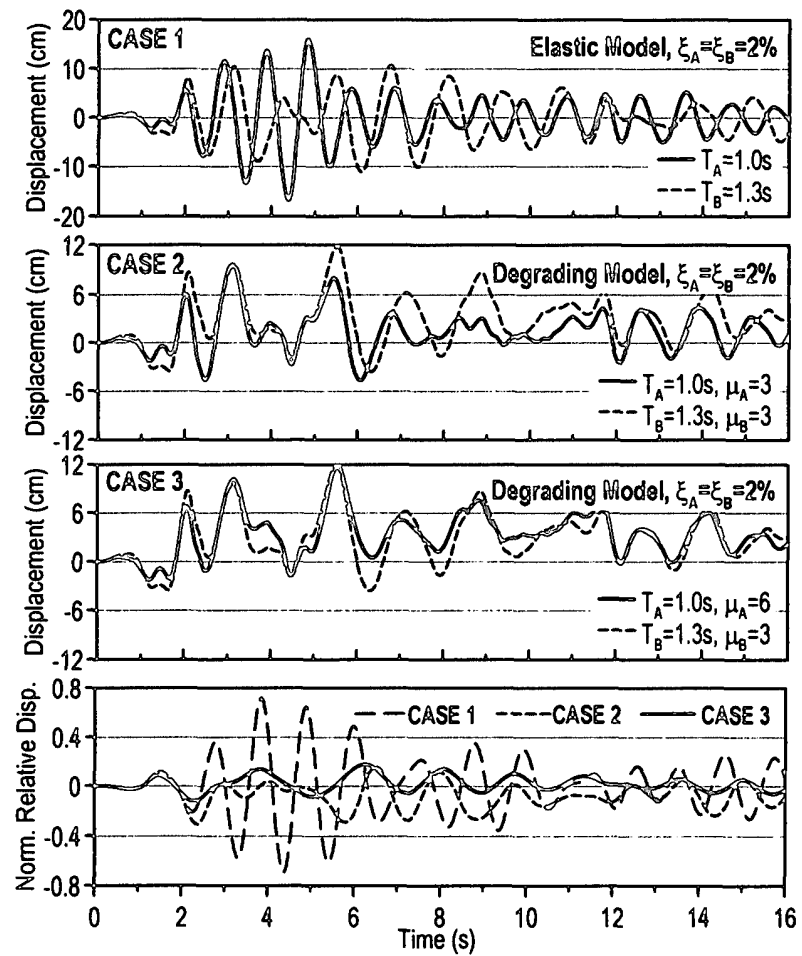

Fignre 3. Time History Respomses of the Systems im Three Cases. 
Case 1: Systems are elastic, and only small damping is given. Thus, they must vibrate mostly out-of-phase.

Case 2: Systems are inelastic, and designed to develop $\mu_{\mathrm{A}}=\mu_{\mathrm{B}}=3$. In-phase motion is promoted due to the hysteretic damping.

Case 3: Systems are inelastic, and designed to develop distinct values of $\mu_{\mathrm{A}}=6$ and $\mu_{\mathrm{B}}=3$. Like case 2 , in-phase motion develops due to hysteretic damping. In addition, although $T_{\mathrm{B}} / T_{\mathrm{A}}=1.3$, different $\mu_{\mathrm{A}}$ and $\mu_{\mathrm{B}}$ causes $T_{\mathrm{B}}^{*} / T_{\mathrm{A}}^{*} \approx 1$, leading to strong in-phase motion (Sec. 3.2).

Table 1. Results of Three Considering Cases.

\begin{tabular}{|c|c|c|c|c|c|c|c|}
\hline \multirow{2}{*}{ Case } & \multicolumn{2}{|c|}{ Ductility } & \multicolumn{3}{|c|}{ Peak Disp. (cm) } & \multirow{2}{*}{$\frac{u_{r e-1}}{\max \left(u_{\mathrm{A}}, u_{\mathrm{B}}\right)}$} & \multirow{2}{*}{$\frac{u_{\mathrm{rel}}}{u_{\mathrm{A}}+u_{\mathrm{B}}}$} \\
\hline & $\mu_{\mathrm{A}}$ & $\mu_{\mathrm{B}}$ & $u_{\mathrm{A}}$ & $u_{\mathrm{B}}$ & $u_{\mathrm{rel}}$ & & \\
\hline 1 & 1 & 1 & 16.81 & 11.09 & 20.02 & 1.19 & 0.72 \\
\hline 2 & 3 & 3 & 9.70 & 11.77 & 6.50 & 0.55 & 0.30 \\
\hline 3 & 6 & 3 & 11.84 & 11.77 & 4.23 & 0.57 & 0.18 \\
\hline
\end{tabular}

As Fig. 3a shows, Case 1 develops out-of-phase movement between the elastic systems A and B due to their different periods. In contrast, the responses of inelastic systems in Cases 2 and 3 are significantly in phase (Figs. 3b, and 3c). Fig. 3d plots $u_{\text {rel }}(t) /\left(u_{\mathrm{A}}+u_{\mathrm{B}}\right)$, which highlights increasing trend of the in-phase motion in the order of Cases 1, 2, and 3. Table 1 lists magnitudes of each response quantity.

The SPD, SRSS, and ABS rules are used to estimate $u_{\text {rel }}$ of the above three cases by using the peak displacements $u_{\mathrm{A}}, u_{\mathrm{B}}$ obtained from the time history analyses. In case of the SPD method, the values are also divided by the yield displacements to calculate $\mu_{\mathrm{A},} \mu_{\mathrm{B}}$, and the cross correlation $\rho_{\mathrm{AB}}$ (Eqs. 5 and 6 ).

Table 2 indicates superior prediction of $u_{\text {rel }}$ by the SPD rule. The errors of the SRSS and ABS rules increase, especially when buildings exhibit large inelastic deformations. Eqs. 4 to 6 of the SPD rule, therefore, could clarify the complex effects from the initial vibration periods, viscous damping ratios, and ductility demands varied herein. This point will be further demonstrated below.

Table 2. Approximation Results Using SPD and Other Methods.

\begin{tabular}{|c|c|c|c|c|c|c|c|c|}
\hline \multirow{2}{*}{ Case } & \multicolumn{4}{|c|}{ Effective Parameters } & \multirow[b]{2}{*}{$\rho_{\mathrm{AB}}$} & \multirow{2}{*}{$\frac{u_{\text {rel }}(\mathrm{SPD})}{u_{\mathrm{rel}}(\mathrm{TH})}$} & \multirow{2}{*}{$\frac{u_{\mathrm{rel}}(\mathrm{SRSS})}{u_{\mathrm{rel}}(\mathrm{TH})}$} & \multirow{2}{*}{$\frac{u_{\mathrm{Tel}}(\mathrm{ABS})}{u_{\mathrm{rel}}(\mathrm{TH})}$} \\
\hline & $T_{A}^{*}$ & $T_{B}^{*}$ & $\xi_{A}^{*}$ & $\xi_{B}^{*}$ & & & & \\
\hline 1 & 1.00 & 1.30 & 0.02 & $\overline{0.02}$ & 0.02 & 1.00 & 1.01 & 1.39 \\
\hline 2 & 1.36 & 1.77 & 0.32 & 0.32 & 0.85 & 0.96 & 2.35 & 3.30 \\
\hline 3 & 1.90 & 1.77 & 0.70 & 0.32 & 0.91 & 1.19 & 3.95 & 5.58 \\
\hline
\end{tabular}

\subsection{Trends of Vibration Phase}

Fig. 4 plots cross correlation coefficients $\rho_{\mathrm{AB}}$ (Eq. 5) in order to illustrate general trends of systems' phase.

For elastic systems (Fig. 4a), the $\rho_{\mathrm{AB}}$ is high only if both $T_{\mathrm{B}} / T_{\mathrm{A}} \approx 1$ and $\xi_{\mathrm{B}} / \xi_{\mathrm{A}} \approx 1$, and it is very low otherwise (Case 1).

For inelastic systems (Figs. $4 \mathrm{c}$ and $4 \mathrm{~d}$ ), however, $T_{\mathrm{B}} / T_{\mathrm{A}} \neq 1$ can lead to the largest $\rho_{\mathrm{AB}}$, depending on $\mu_{\mathrm{A}}$ and $\mu_{\mathrm{B}}$ (Cases 2 and 3). This is because the effective period and damping, instead of initial period and damping, governs $\rho_{\mathrm{AB}}$ (Eq. 5) when systems are inelastic. Case 3 gives a typical example, where $T_{\mathrm{B}}^{*} / T_{\mathrm{A}}^{*} \approx 0.93$ (Table 2) in contrast to $T_{\mathrm{B}} / T_{\mathrm{A}}=1.3$, and it gave the smallest $u_{\text {ret }}$ among all cases (Tables 1 and 2, Fig. 3).

Since $T^{*}$ and $\xi^{*}$ are affected by the ductility demand $\mu$, Fig. 4 provides the direct and useful information regarding the effect of $\mu$. The peaks of the $\rho_{\mathrm{AB}}$-curves are close to 1.0 for a wide range of $T_{\mathrm{B}} / T_{\mathrm{A}}$ when $\mu>2$, indicating importance of including even moderate amount of yielding.

Thus, large $\rho_{\mathrm{AB}}$ results even when the initial period ratio $T_{\mathrm{B}} / T_{\mathrm{A}} \neq 1$, and maximum $\rho_{\mathrm{AB}}$ is obtained when systems $\mathrm{A}$ and $\mathrm{B}$ have different $\mu$ 's. This is the reason why Case 3 shows more in-phase motion than Case 2.

\section{SIMPLIFIED SPD-BASED METHOD}

As explained in Sec. 3.1, the SPD rule can perform well when peak
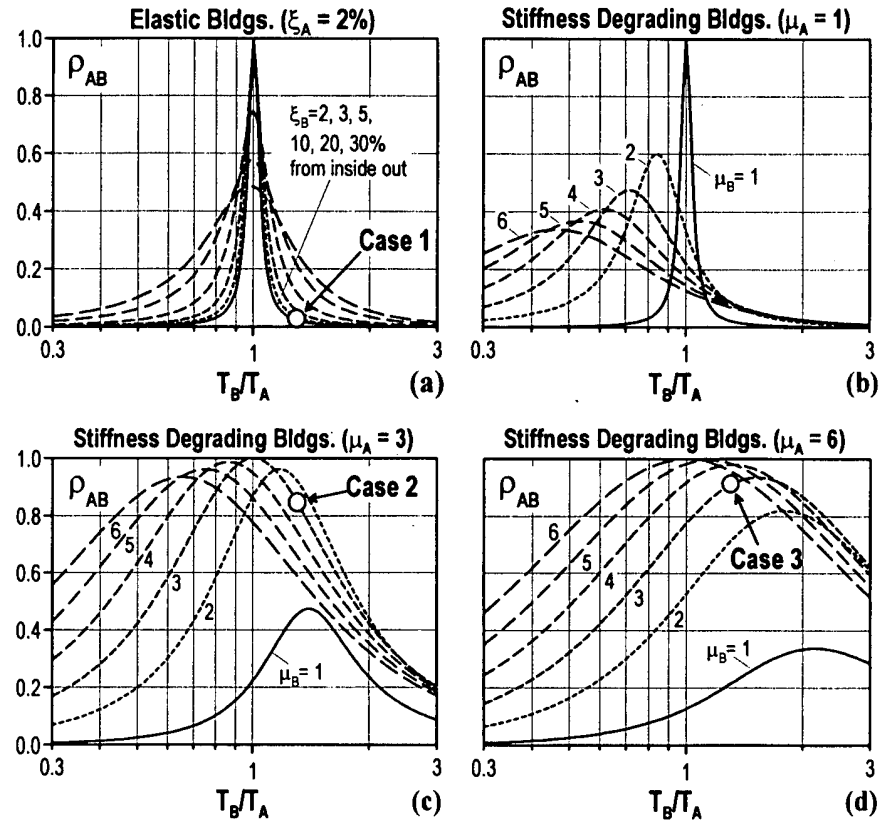

Figure 4. General Trends of Buildings' Phase $\left(\rho_{\mathrm{AB}}\right)$.

displacements $u_{\mathrm{A}}$ and $u_{\mathrm{B}}$ are accurately given. Inelastic spectrum provides these values, but elastic spectrum is preferred from a practical reason. This chapter, therefore, proposes a "simplified SPD-based method" that combines the SPD rule and the elastic spectrum.

\subsection{Inelastic Displacement Prediction by Elastic Spectrum}

Studies have been conducted worldwide to predict inelastic response via elastic spectrum. They utilize the strong correlation between the ductility demand $\mu$ and the strength reduction factor $R_{\mu}$ such as (Fig. 5):

$$
R_{\mu}=\frac{Q_{e}}{Q_{y}}=\frac{\Delta_{e}}{\Delta_{y}}
$$

where $Q_{y}, \Delta_{y}=$ yield shear and yield displacement of the system given, and $Q_{e}, \Delta_{e}=$ base shear and displacement when the system is presumed to behave elastically. Note that the above displacements are defined at the effective height ${ }^{9)} H_{\text {eff }}$ of the building.

The $\mu-R_{\mu}$ relationships have been proposed by Newmark and Hall ${ }^{10)}$, Uang ${ }^{11)}$, and others. In the present study we will utilize Nassar and Krawinkler's rule ${ }^{12)}$ as follows:

$$
\begin{aligned}
& \mu=1+\frac{R_{\mu}^{c}-1}{c} \\
& c=\frac{T^{a}}{1+T^{a}}+\frac{b}{T}
\end{aligned}
$$

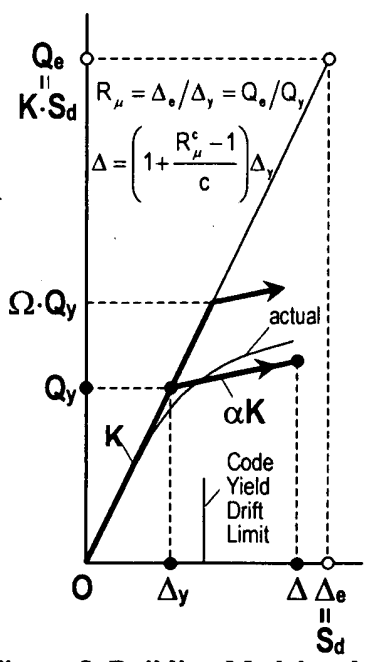

Figure 5. Building Model and Elastic Approximation. where $a$ and $b$ depend on the strain-hardening ratio $\alpha$. By applying linear regression to the $\alpha$-values tabulated in Ref. 12,

$$
a=1.02-2.18 \alpha, \quad b=0.41-1.21 \alpha \quad(\alpha \leq 0.1)
$$

Unlike the equal energy rule ${ }^{10)}$ or the equal displacement rule ${ }^{(0), 11)}$, Eq. 8 is applicable to the whole range of short to long period, and considers the fact ${ }^{(1)}-{ }^{14)}$ that for a short period $R_{\mu}$ is less than $\mu$. Eq. 8 was already. validated $^{12)}$ for $\mu$-value up to 8 .

Once $\Delta_{e}$ is estimated from an elastic spectrum, $\mu$ is obtained from Eqs. 7 and 8, and the peak inelastic displacement $\Delta$ (Fig.5) at height $H_{e f f}$ is 


$$
\Delta=\mu \cdot \Delta_{y}
$$

Following Refs. 12,11 and 16 , the damping ratio shall be $5 \%$ when using the elastic spectrum.

\subsection{Step-by-Step Procedure for Simplified SPD-Based Method}

For simplified prediction of $u_{\text {rel }}$ without conducting time history analysis, we combine the SPD rule with elastic response spectrum. The height of building $\mathrm{A}$ is set equal to or greater than that of building $\mathrm{B}$, i.e., $H_{\mathrm{A}} \geq H_{\mathrm{B}}$ will be considered (Fig. 1).

The procedure obtains the following parameters in order:

(1) Elastic displacements $\Delta_{e A}$ and $\Delta_{e B}$ from elastic spectrum.

(2) Inelastic displacements $\Delta_{A}$ and $\Delta_{B}$ using Eqs. 7 to 10.

(3) Inelastic displacements $u_{\mathrm{A}}$ and $u_{\mathrm{B}}$ at the common critical height.

(4) Effective periods $T_{\mathrm{A}}^{\circ}$ and $T_{\mathrm{B}}^{*}$, damping ratio $\xi_{\mathrm{A}}^{*}$ and $\xi_{\mathrm{B}}^{*}$ from Eqs. 6.

(5) Cross correlation $\rho_{\mathrm{AB}}$ from Eq. 5, and $u_{\mathrm{rel}}(\mathrm{SPD})$ from Eq. 4.

Note that $\Delta=$ displacement at each building's effective height which may differ from each other, and $\mathrm{u}=$ displacement at a common critical elevation ( $=H_{\mathrm{B}}$ ) of the two buildings where pounding is likely (Fig. 1).

In the present study, a simple straight-line building deformation mode is assumed. For step (3) above, therefore, effective height $H_{e f f}=2 H / 3$ is considered for each building, and the following relationship is used:

$$
u_{\mathrm{A}}=1.5\left(H_{\mathrm{B}} / H_{\mathrm{A}}\right) \Delta_{\mathrm{A}}, \quad u_{\mathrm{B}}=1.5 \Delta_{\mathrm{B}}
$$

\subsection{Building Models Consistent with Code}

Building models to be used in the following sections will be defined here. The preliminary data required for the application of the SPD-based method are the initial period $T$ and the yield displacement $\Delta_{y}$ of each building. From now on, $T$ is assumed to coincide with that given by the Japanese Seismic Code ${ }^{15)}$, i.e.,

$$
T=0.03 H \quad \text { (Steel Bldg.), } T=0.02 H \text { (Concrete Bldg.) }
$$

where $H=$ total height of the building in meters.

Building yield shear is set to $\Omega \cdot Q_{y}$, where $\Omega=$ overstrength factor, and $Q_{y}=$ yield shear required by the code such as (Fig. 5):

$$
Q_{y}=C_{0} \cdot R_{t} \cdot W
$$

In Eq. 13, $C_{0}=0.25$ and 0.30 are assumed for the steel and concrete buildings, respectively. The required values are somewhat arbitrary as long as $C_{0} \geq 0.2$, and they are made equal to the $D_{s}$-factors ${ }^{15)}$. Indeed, these higher values may better approximate the actual behavior, as suggested by Fig. 5 . Note also that the overstrength factor $\Omega$ will be varied later (Fig. 5), making the specific $C_{0}$-value less significant in such a study. Also, all the buildings in the present study appear to have enough stiffness to satisfy the code drift angle limit 1/200 (Fig. 5).

The design spectral coefficient $R_{t}$ is obtained from the formula below

$$
R_{t}= \begin{cases}1 & ; T<T_{c} \\ 1-0.2\left(T / T_{c}-1\right)^{2} & ; T_{c} \leq T<2 T_{c} \\ 1.6 T_{c} / T & ; 2 T_{c} \leq T\end{cases}
$$

where medium soil is assumed and the critical period $T_{c}=0.6 \mathrm{~s}$. Based on these, the yield displacement $\Delta_{y}$ at height $H_{e f f}$ is calculated as:

$$
\Delta_{y}=C_{0} \cdot R_{t} \cdot g(T / 2 \pi)^{2}
$$

\subsection{Example Application}

This section demonstrates an example application of the SPD-based simplified method to estimate the relative displacement $u_{\text {rel }}$.

Consider 15-story building A and 12-story building $\mathrm{B}$. The buildings' heights are $H_{\mathrm{A}}=60 \mathrm{~m}$ and $H_{\mathrm{B}}=48 \mathrm{~m}$, respectively. They, are designed as ductile steel moment frames. Accordingly, Eqs. 12 to 15 give

$$
\begin{array}{ll}
T_{\mathrm{A}}=0.03 H_{\mathrm{A}}=1.80 \mathrm{~s}, & \Delta_{y \mathrm{~A}}=10.7 \mathrm{~cm}, \\
T_{\mathrm{B}}=0.03 H_{\mathrm{B}}=1.44 \mathrm{~s}, & \Delta_{y \mathrm{~B}}=8.6 \mathrm{~cm} .
\end{array}
$$

Initial damping ratio $\xi=0.02$, and strain-hardening ratio $\alpha=0.05$ is considered. The buildings are subjected to the 1994 Northridge earthquake (Newhall NS record, $0.59 \mathrm{~g}$ ) scaled to $0.4 \mathrm{~g}$ peak acceleration. See the following steps:

(1) The 5\% damping elastic displacement spectrum (Sec. 4.1) of the scaled Newhall record gives

$$
\begin{aligned}
& \Delta_{e \mathrm{~A}}=S_{d}\left(T_{\mathrm{A}}, 0.05\right)=28.1 \mathrm{~cm}, \\
& \Delta_{e \mathrm{~B}}=S_{d}\left(T_{\mathrm{B}}, 0.05\right)=29.3 \mathrm{~cm} .
\end{aligned}
$$

(2) Using the strength reduction factor of Eq. 7, ductility demands and inelastic displacements are estimated from Eqs. 8 and 10.

$$
\begin{array}{ll}
\mu_{\mathrm{A}}=1+\left\{\left(\Delta_{e \mathrm{~A}} / \Delta_{y \mathrm{~A}}\right)^{0.82}-1\right\} / 0.82=2.47, & \Delta_{\mathrm{A}}=\mu_{\mathrm{A}} \Delta_{y \mathrm{~A}}=26.5 \mathrm{~cm} \\
\mu_{\mathrm{B}}=1+\left\{\left(\Delta_{e \mathrm{~B}} / \Delta_{y \mathrm{~B}}\right)^{0.83}-1\right\} / 0.83=3.13, & \Delta_{\mathrm{B}}=\mu_{\mathrm{B}} \Delta_{y \mathrm{~B}}=26.9 \mathrm{~cm}
\end{array}
$$

(3) The critical height is $H_{\mathrm{B}}$ (Fig. 1a), and from Eq. 11 .

$$
\begin{array}{ll}
u_{\mathrm{A}}=1.5\left(H_{\mathrm{B}} / H_{\mathrm{A}}\right) \Delta_{\mathrm{A}} & =31.8 \mathrm{~cm} \\
u_{\mathrm{B}}=1.5 \Delta_{\mathrm{B}} & =40.2 \mathrm{~cm}
\end{array}
$$

(4) Effective periods and effective damping are estimated from Eq. 6 a.

$$
\begin{array}{ll}
T_{\mathrm{A}}^{\circ}=T_{\mathrm{A}}\left[1+0.09\left(\mu_{\mathrm{A}}-1\right)\right]=2.04 ; & \xi_{\mathrm{A}}^{*}=\xi_{\mathrm{A}}+0.084\left(\mu_{\mathrm{A}}-1\right)^{1.3}=0.16 \\
T_{\mathrm{B}}^{\circ}=T_{\mathrm{B}}\left[1+0.09\left(\mu_{\mathrm{B}}-1\right)\right]=1.72 ; & \xi_{\mathrm{B}}^{\circ}=\xi_{\mathrm{B}}+0.084\left(\mu_{\mathrm{B}}-1\right)^{1.3}=0.24
\end{array}
$$

(5) Substituting the above into Eq. 5, we calculate $\rho_{\mathrm{AB}}=0.84$. The peak relative displacement $u_{\text {rel }}(\mathrm{SPD})$ is estimated as

$$
u_{\mathrm{rel}}(\mathrm{SPD})=\sqrt{u_{\mathrm{A}}^{2}+u_{\mathrm{B}}^{2}-2 \rho_{\mathrm{AB}} u_{\mathrm{A}} u_{\mathrm{B}}}=22.04 \mathrm{~cm}=1.02 u_{\mathrm{rel}}(\mathrm{TH})
$$

The result of inelastic time history analysis $u_{\mathrm{rel}}(\mathrm{TH})=21.60 \mathrm{~cm}$, after averaging $21.45 \mathrm{~cm}$ and $21.74 \mathrm{~cm}$ obtained using positive and negative directions of the earthquake. If we use ABS- and SRSS-based methods,

$$
\begin{aligned}
& u_{\mathrm{rel}}(\mathrm{ABS})=u_{\mathrm{A}}+u_{\mathrm{B}}=72.1 \mathrm{~cm}=3.34 u_{\mathrm{rel}}(\mathrm{TH}) \\
& u_{\mathrm{rel}}(\mathrm{SRSS})=\sqrt{u_{\mathrm{A}}^{2}+u_{\mathrm{B}}^{2}}=51.3 \mathrm{~cm}=2.38 u_{\mathrm{rel}}(\mathrm{TH})
\end{aligned}
$$

These indicate that the SPD-based method provides by far the most accurate estimate for $u_{\text {rel }}$. The ABS-based method gives excessive conservatism. Clearly, the errors from the ABS- and SRSS-based methods stem from their inability to account for the vibration phase of the two buildings.

\subsection{Relative Displacement under Code $\mathbb{D}$ esign Basis Spectrum}

It is assumed that the code-compatible steel buildings are subjected to the earthquake whose pseudo-acceleration spectrum $S_{p a}$ has a magnitude of scaled $R_{r} \cdot g$. This section will consider a variety of buildings having $H_{\mathrm{A}}=12 \mathrm{~m} \sim 96 \mathrm{~m}, H_{\mathrm{B}} / H_{\mathrm{A}}=0.4 \sim 0.8$, and overstrength factor $\Omega=1 \sim 3$, as well as various scaling factors of $R_{t} \cdot g$. Since the SRSS- (adopted by IBC20006) and ABS-based methods neglect the vibration phase, trends of relative displacement $u_{\text {rel }}$ are discussed below by using only the SPD-based method. Yet, the following graphs clearly illustrate again the inaccuracy of the two methods compared to the SPD-based method.

Fig. 6a shows a case where $H_{\mathrm{A}}$ is varied. Apparently, when $H_{\mathrm{B}} / H_{\mathrm{A}}$ approaches 1 , the dynamic properties of buildings become similar due to the code specifications, and they have the tendency to vibrate in-phase. SPD-based method captures this remarkable aspect, and explains why the $u_{\text {rel }}$ of two very tall buildings is similar and somewhat less than that of a very tall building and a short building. Moreover, at the critical elevation $H_{\mathrm{B}}$, the $u_{\text {rel }}$ is almost proportional to $H_{\mathrm{A}}$ (Fig. 6) regardless of $H_{\mathrm{B}} / H_{\mathrm{A}}$ as mentioned above. With $S_{p a}=R_{t} \cdot g$ and the overstrength $\Omega=1$, the important relationship $u_{\text {rel }} \approx 0.006 H_{\mathrm{A}}$ is obtained from Fig. $6 \mathrm{a}$.

Fig. $6 \mathrm{~b}$ illustrates a case where $H_{\mathrm{A}}=60 \mathrm{~m}$ and $S_{p a}$ is scaled to different levels. This figure again reinforces the fact that inelastic displacement contributes importantly to the in-phase vibration between adjacent buildings. Under the stronger earthquake, $u_{\mathrm{A}}$ and $u_{\mathrm{B}}$ increase obviously, 

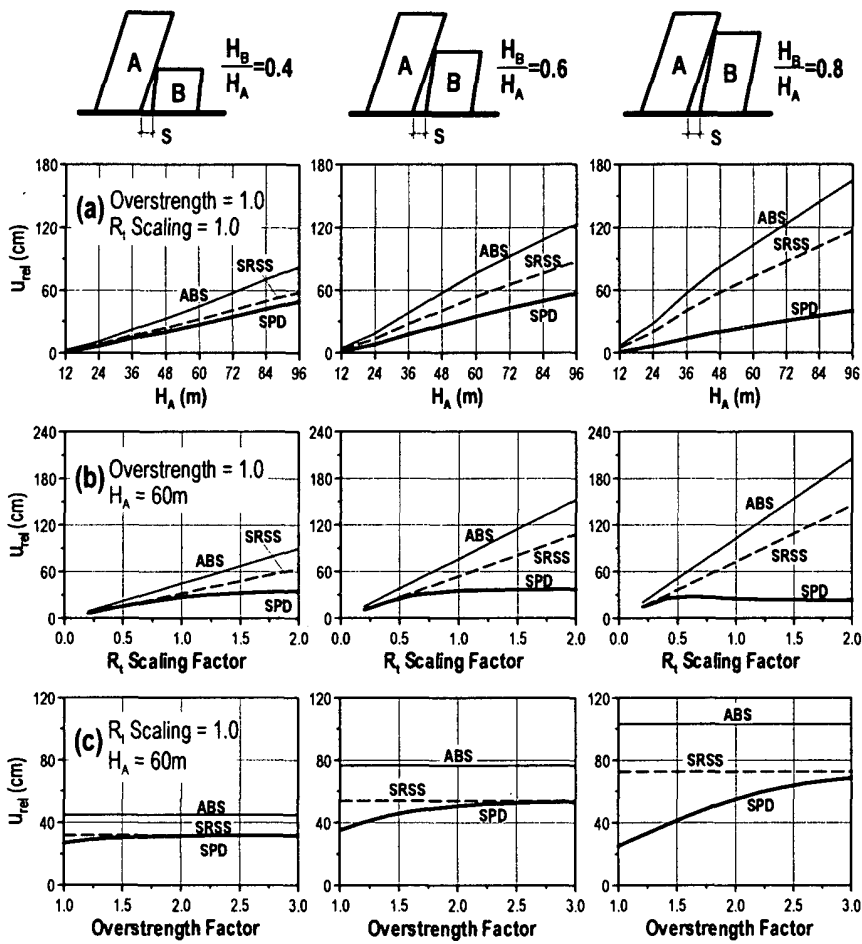

Figure 6. Dependency of $u_{\text {rel }}$ Between 2 Steel MRFs on: (a) Building Height, (b) Earthquake Level, and (c) Building Overstrength.

but since $\rho_{\mathrm{AB}}$ also increases, Eq. 4 gives almost the same relative displacement $u_{\text {rel }}$ (Fig. 6b). Thus, the aforementioned rule of $u_{\text {rel }} \approx$ $0.006 H_{\mathrm{A}}$ is still applicable for the earthquake exceeding the code design basis spectrum, as long as the building overstrength $\Omega=1$.

Fig. $6 \mathrm{c}$ illustrates a case where $H_{\mathrm{A}}=60 \mathrm{~m}$ and overstrength $\Omega$ is varied to more than 1 . Since larger $\Omega$ leads to less inelastic deformation, the trend of in-phase vibration reduces, which means that stronger buildings have larger $u_{\mathrm{rel}}$. Based on this and considering the above findings (Figs. $6 \mathrm{a}, \mathrm{b})$, regardless of building heights $H_{\mathrm{A}}, H_{\mathrm{B}}$, and earthquake intensity level, $u_{\text {rel }} \approx 0.01 H_{\mathrm{A}}$ may be used conservatively as long as $\Omega \leq 2$.

\section{VALIDATION OF SIMPLIFIED SPD-BASED METHOD}

\subsection{Parameters Considered for Validation}

The example in the previous chapter is now extended in order to examine the accuracy of the SPD-based method, and to obtain the general trend of $u_{\text {rel }}$ between the building pairs consisting of various steel and concrete frames.

Buildings have 8 different heights of $3,6,9,12,15,18,21$, and 24 stories with a common story height of $4 \mathrm{~m}$. For building pairs $\mathrm{A}$ and $\mathrm{B}$, all possible combinations of 8 different heights are considered with the condition of $H_{\mathrm{A}} \geq H_{\mathrm{B}}$ (Fig. 1). The total number of building pairs is 36 .

Additionally, 4 cases of material type combinations for buildings $A$ and $B$ are assumed: steel vs. steel; concrete vs. concrete; steel vs.
Table 3. Earthquakes Used in the Validation Study.

\begin{tabular}{|c|c|c|c|c|c|c|c|}
\hline $\begin{array}{l}\text { Rec } \\
\text { No. }\end{array}$ & \multicolumn{2}{|c|}{ Earthquake } & \multirow{3}{*}{$\begin{array}{c}\begin{array}{c}\text { PGA } \\
\text { (g) }\end{array} \\
0.349 \\
0.214\end{array}$} & \multirow{3}{*}{$\begin{array}{l}\text { Rec } \\
\text { No. }\end{array}$} & \multicolumn{2}{|c|}{ Earthquake } & \multirow{2}{*}{$\begin{array}{r}\text { PGA } \\
\text { (g) } \\
0.880 \\
\end{array}$} \\
\hline 1 & \multirow{2}{*}{$\begin{array}{c}\text { Imperial Valley } \\
1940\end{array}$} & \multirow{2}{*}{\begin{tabular}{|l|} 
El Centro NS \\
El Centro EW \\
\end{tabular}} & & & \multirow{2}{*}{$\begin{array}{c}\text { Iran } \\
1978 \\
\end{array}$} & Tabas N074E & \\
\hline 2 & & & & & & Tabas N344E & 0.938 \\
\hline 3 & \multirow{2}{*}{$\begin{array}{c}\text { Kern County } \\
1952\end{array}$} & Taft N02IE & 0.156 & 19 & \multirow{4}{*}{$\begin{array}{c}\text { Northridge } \\
1994\end{array}$} & Newhall NS & 0.590 \\
\hline 4 & & Taft NI11E & 0.179 & 20 & & Newhall EW & 0.583 \\
\hline 5 & \multirow{2}{*}{$\begin{array}{c}\text { Tokachi oki } \\
1968 \\
\end{array}$} & Hachinohe NS & 0.278 & 21 & & Sylmar NS & 0.844 \\
\hline 6 & & Hachinohe EW & 0.204 & 22 & & Sylmar EW & 0.605 \\
\hline 7 & \multirow{6}{*}{$\begin{array}{c}\text { Hyogoken } \\
\text { Nanbu } \\
1995\end{array}$} & JMA Kobe NS & 0.837 & 23 & \multirow{6}{*}{$\begin{array}{c}\text { Chi Chi } \\
\text { (Taiwan) } \\
1999\end{array}$} & TCU065 NS & 0.575 \\
\hline 8 & & JMA Kobe EW & 0.632 & 24 & & TCU065 EW & 0.790 \\
\hline 9 & & Fukiai N240E & 0.701 & 25 & & TCU068 NS & 0.369 \\
\hline 10 & & Fukiai N330E & 0.818 & 26 & & TCU068 EW & 0.512 \\
\hline 11 & & JR Takatori NS & 0.618 & 27 & & TCU074 NS & 0.376 \\
\hline 12 & & JR Takatori EW & 0.670 & 28 & & TCU074 EW & 0.598 \\
\hline 13 & \multirow{2}{*}{$\begin{array}{c}\text { Miyagiken oki } \\
1978 \\
\end{array}$} & Tohoku NS & 0.263 & 29 & \multirow{3}{*}{$\begin{array}{c}\text { Kocaeli } \\
\text { (Turkey) } \\
1999\end{array}$} & Ypt NS & 0.329 \\
\hline 14 & & Tohoku EW & 0.207 & 30 & & Ypt EW & 0.235 \\
\hline 15 & \multirow{3}{*}{$\begin{array}{c}\text { Kushiro oki } \\
1993 \\
\end{array}$} & Kushiro N063E & 0.707 & 31 & & Sakarya & 0.415 \\
\hline 16 & & Kushiro N153E & 0.588 & .32 & \multirow{2}{*}{ Artificial } & BCJ-LI & 0.212 \\
\hline & & & & 33 & & $\mathrm{BCJ}-\mathrm{L} 2$ & 0.363 \\
\hline
\end{tabular}

concrete; and concrete vs. steel, respectively. These cases are listed in Table 4. In total, the number of building pairs is 144 [(36 height combinations) $\mathrm{x}$ (4 material type combinations)].

For each building pair, 31 past earthquakes and 2 artificial earthquakes (Table 3) are used, and each record is applied in both positive and negative directions. The records cover a variety of seismic intensities, and it is reasonable to scale them to the same peak ground acceleration (PGA). Thus, 4 different PGA scales of $0.2 \mathrm{~g}, 0.4 \mathrm{~g}, 0.6 \mathrm{~g}$, and $0.8 \mathrm{~g}$ are considered for each record. In total, the number of earthquakes considered for each building pair is 264 [( 33 earthquakes) $\times$ ( 2 directions) $x$ (4 PGA scales)].

Fig. 7 shows the mean acceleration spectrum and mean \pm standard deviation of 33 records scaled to $0.4 \mathrm{~g}$. Fig. 7 also shows $R_{t} \cdot g$ curve for the medium soil condition. Yield strengths of 8 steel buildings and 8 concrete buildings are also plotted, respectively.

Using the elastic spectrum of each earthquake, inelastic peak displacement is estimated, and used for all the SPD-, SRSS-, and ABS-based methods. Also, in order to obtain exact solution for $u_{\text {rel }}$,

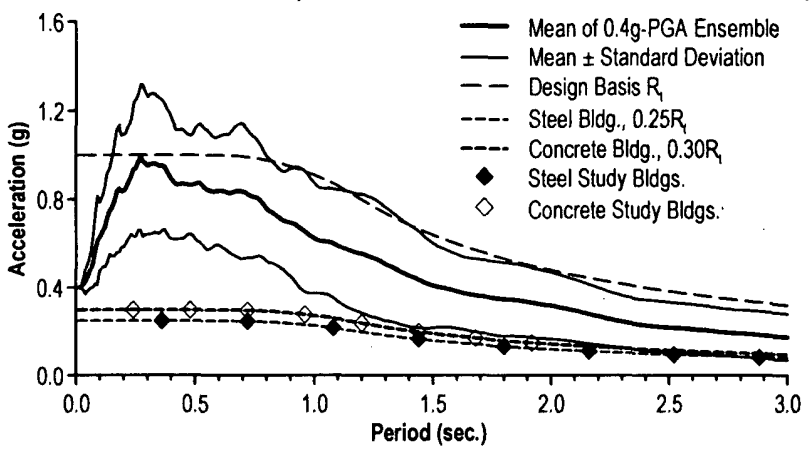

Figure 7. Mean and Deviation of 33 Acceleration Spectra (PGA=0.4g, 5\% Damping), Design Spectrum, and Strengths of Designed Buildings.

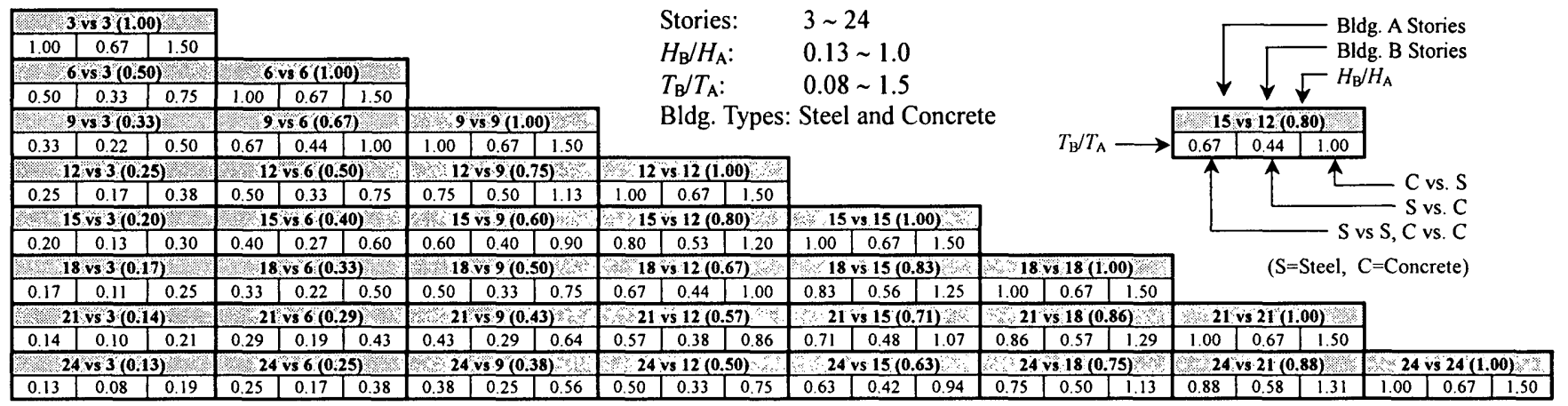

Table 4. Building Pairs A and B Used in Validation Study. 
dynamic time history analyses are conducted using a SDOF nonlinear analysis program NONSPEC ${ }^{17}$. In summary, this validation study examines a total of 38,016 cases [(144 building pairs) $x$ ( 264 scaled records)].

\subsection{Validation Results}

For each of the cases mentioned above, the ratios of $u_{\text {rel }}(\mathrm{SPD})$, $u_{\text {rel }}(\mathrm{SRSS})$, and $u_{\text {rel }}(\mathrm{ABS})$ to the $u_{\text {rel }}(\mathrm{TH})$ are obtained, and they are averaged over 36 height combinations and 2 earthquake directions per combination of material type, earthquake, and PGA scale. The average values are shown in Fig. 8. Next, such values are further averaged over 33 earthquakes, and the results are summarized in Table 5 .

Fig. 8 shows that $u_{\text {rel }}(\mathrm{SPD}) / u_{\text {rel }}(\mathrm{TH}) \approx 1$ for most cases, indicating superior accuracy of the SPD-based method. ABS- or SRSS-based method appears to be largely conservative, as the PGA scale increases. This is because they do not account for the important effect of inelastic deformation, which, under stronger earthquake causes more in-phase motion between the two buildings. The standard deviation in Table 5 (number in parentheses) clearly strengthens the stable degree of SPD-based method. Although we observe some scattering of its estimates for stronger earthquakes in $0.6 \mathrm{~g}$ and $0.8 \mathrm{~g}$ PGA ensembles, the scattering is still much less than those of SRSS- or ABS-based method.

The important effect of inelastic in-phase motion is seen especially for the strong earthquakes like Kobe Japan (earthquakes 7 to 12), Iran and Northridge (earthquakes 17 to 22). These earthquakes, even scaled to the same PGA as other earthquakes, force each building to deform larger due to their higher spectral values over a wide period range, but they also produce at the same time more in-phase motion between the two buildings. Such tendencies are accurately predicted by the simplified SPD-based method.

The SPD-method is also accurate for less severe earthquakes like Imperial Valley, Kern County and Hachinohe (earthquakes 1 to 6) or Kocaeli and BCJ (earthquakes 29 to 33). When PGA is $0.2 \mathrm{~g}$, the SRSS-based method is almost as accurate as the SPD-based method. This is because the average spectrum of $0.2 \mathrm{G}$ earthquakes approaches the buildings' design strength spectra, as can be imagined from Fig. 7. Thus, the buildings responded almost elastically, resulting in the small effective damping and consequently the small correlation $\rho_{\mathrm{AB}}$, which made Eq. $3 \mathrm{~b}$ and 4 produce almost the same estimate for $u_{\text {rel }}$. This trend, therefore, differs from what is discussed in Sec. 3.2.

Table 5. Average Accuracy of SPD, SRSS and ABS Methods ${ }^{\dagger}$.

\begin{tabular}{|c|c|c|c|c|c|c|c|c|c|c|c|c|}
\hline \multirow{2}{*}{ Case } & \multicolumn{3}{|c|}{ PGA $=0.2 \mathrm{~g}$} & \multicolumn{3}{|c|}{ PGA $=0.4 \mathrm{~g}$} & \multicolumn{3}{|c|}{ PGA $=0.6 \mathrm{~g}$} & \multicolumn{3}{|c|}{ PGA $=\mathbf{0 . 8} \mathbf{g}$} \\
\hline & SPD & SRSS & ABS & SPD & SRSS & ABS & SPD & SRSS & ABS & SPD & SRSS & ABS \\
\hline $\begin{array}{l}\text { Steel } \\
\text { vs. } \\
\text { Steel }\end{array}$ & $\begin{array}{c}1.01 \\
(0.18)\end{array}$ & \begin{tabular}{|c|}
1.05 \\
$(0.24)$
\end{tabular} & $\begin{array}{c}1.36 \\
(0.38)\end{array}$ & $\begin{array}{c}1.07 \\
(0.25)\end{array}$ & $\begin{array}{c}1.29 \\
(0.48)\end{array}$ & $\begin{array}{c}1.69 \\
(0.73)\end{array}$ & $\begin{array}{c}0.99 \\
(0.31)\end{array}$ & $\mid \begin{array}{c}1.41 \\
(0.66)\end{array}$ & $\begin{array}{c}1.86 \\
(0.99)\end{array}$ & $\begin{array}{c}0.90 \\
(0.35)\end{array}$ & $\mid \begin{array}{c}1.47 \\
(0.84)\end{array}$ & $\begin{array}{c}1.95 \\
(1.24)\end{array}$ \\
\hline $\begin{array}{c}\text { Concrete } \\
\text { vs. } \\
\text { Concrete } \\
\end{array}$ & $\begin{array}{c}1.00 \\
(0.16)\end{array}$ & $\begin{array}{c}1.07 \\
(0.32)\end{array}$ & $\begin{array}{c}1.38 \\
(0.50)\end{array}$ & $\begin{array}{c}1.07 \\
(0.27)\end{array}$ & $\left\{\begin{array}{c}1.45 \\
(0.81)\end{array}\right.$ & $\begin{array}{c}1.91 \\
(1.20)\end{array}$ & $\begin{array}{c}0.98 \\
(0.37)\end{array}$ & $\begin{array}{c}1.63 \\
(1.21)\end{array}$ & $\begin{array}{c}2.17 \\
(1.75)\end{array}$ & $\begin{array}{c}0.90 \\
(0.45)\end{array}$ & $\begin{array}{c}1.70 \\
(1.36)\end{array}$ & \begin{tabular}{|c}
2.27 \\
$(1.96)$
\end{tabular} \\
\hline $\begin{array}{c}\text { Steel } \\
\text { vs. } \\
\text { Concrete } \\
\end{array}$ & $\begin{array}{l}0.99 \\
(0.19)\end{array}$ & $\begin{array}{c}1.02 \\
(0.23)\end{array}$ & $\begin{array}{c}1.36 \\
(0.31)\end{array}$ & $\begin{array}{c}1.08 \\
(0.30)\end{array}$ & $\begin{array}{c}1.30 \\
(0.49)\end{array}$ & $\left\{\begin{array}{c}1.75 \\
(0.69)\end{array}\right.$ & $\begin{array}{c}1.00 \\
(0.39)\end{array}$ & $\begin{array}{c}1.43 \\
(0.70)\end{array}$ & $\begin{array}{c}1.94 \\
(0.97)\end{array}$ & $\begin{array}{c}0.89 \\
(0.45)\end{array}$ & $\begin{array}{c}1.50 \\
(0.84)\end{array}$ & \begin{tabular}{|c}
2.05 \\
$(1.17)$
\end{tabular} \\
\hline $\begin{array}{c}\text { Concrete } \\
\text { vs. } \\
\text { Steel }\end{array}$ & $\begin{array}{c}1.03 \\
(0.22)\end{array}$ & $\begin{array}{c}1.28 \\
(0.58)\end{array}$ & $\begin{array}{c}1.76 \\
(0.80)\end{array}$ & $\begin{array}{c}1.04 \\
(0.32)\end{array}$ & $\left\{\begin{array}{c}1.65 \\
(0.72)\end{array}\right.$ & $\begin{array}{l}2.28 \\
(1.00)\end{array}$ & $\mid \begin{array}{c}0.93 \\
(0.40)\end{array}$ & $\begin{array}{c}1.80 \\
(0.89)\end{array}$ & $\begin{array}{c}2.47 \\
(1.24)\end{array}$ & $\begin{array}{c}0.84 \\
(0.45)\end{array}$ & $\begin{array}{c}1.83 \\
(1.00)\end{array}$ & $\begin{array}{c}2.52 \\
(1.38)\end{array}$ \\
\hline
\end{tabular}

In average, the SPD-based method fulfills the expectations of accuracy as shown in Table 5. However, by careful inspection we also noticed that in the aforementioned strong earthquakes (earthquakes 7 to 12), the degree of accuracy has somehow exhibited rather wide
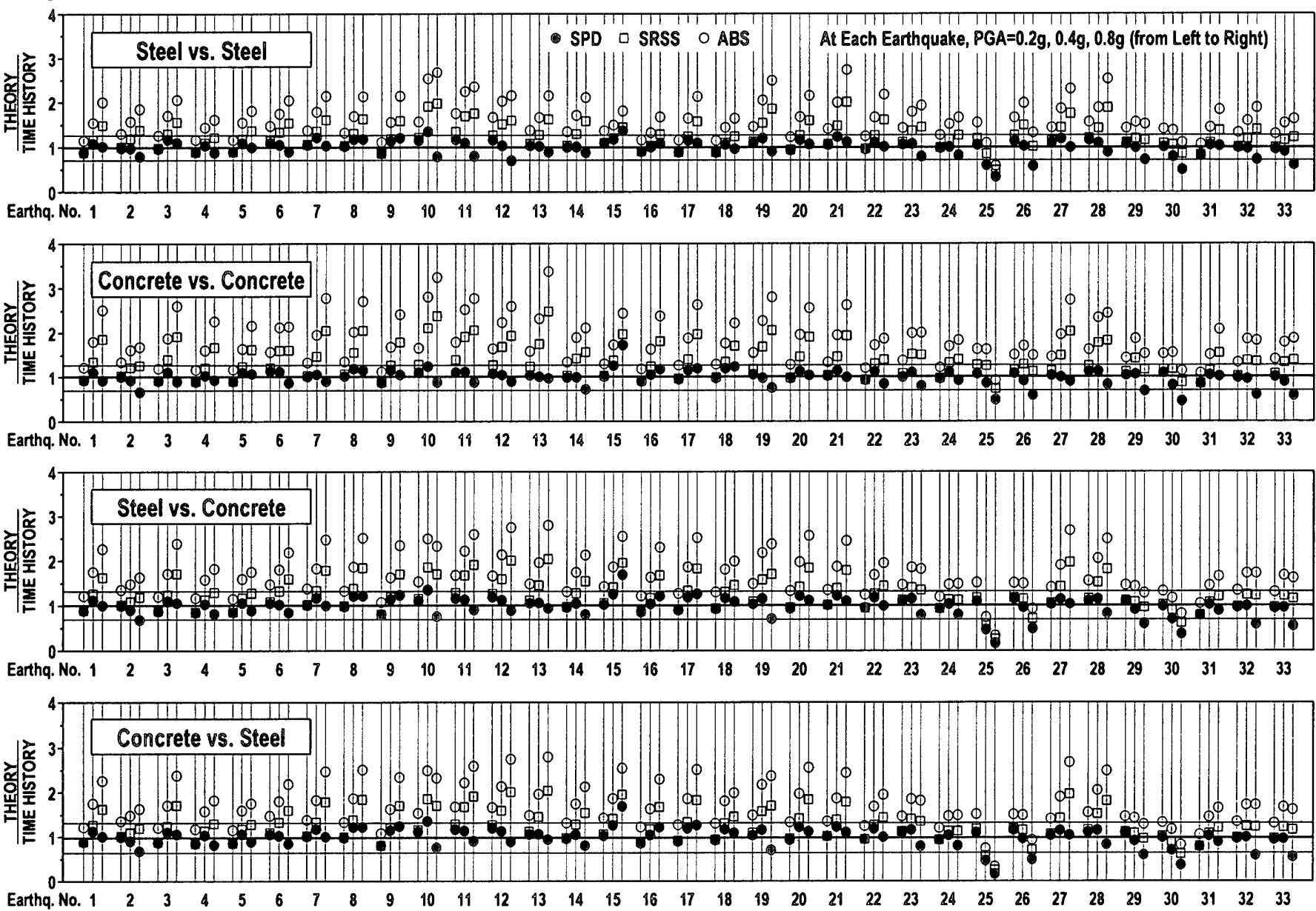

Figure 8. Average Ratios of $u_{\text {rel }}(\mathrm{SPD}), u_{\text {rel }}(\mathrm{SRSS})$, and $u_{\text {rel }}(\mathrm{ABS})$ to Exact Solution $u_{\mathrm{rel}}(\mathrm{TH})$; Each Point Imdicates Average over 72 Cases. (Thick and thin horizontal lines represent average accuracy and average \pm standard deviation of the SPD-based method) 


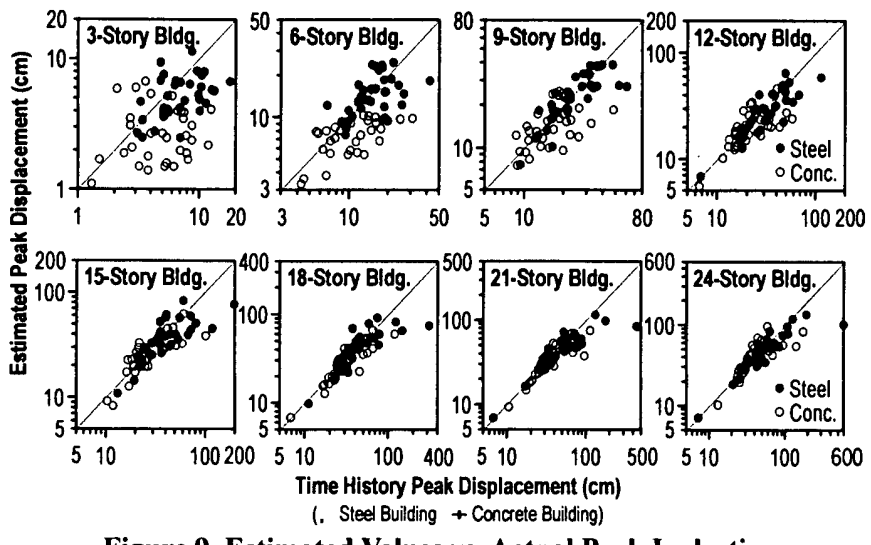

Figure 9. Estimated Values vs. Actual Peak Inelastic Displacements: 0.4g Ground Motion Ensemble.

(66 data point per graph)

variability. Fig. 9 explains this phenomenon using $0.4 \mathrm{~g}$ PGA earthquakes: peak inelastic displacement estimated from the elastic spectrum and Eqs. 7 to 10 are plotted against the accurate time history analysis result, where each data point corresponds to one earthquake of one direction. For short period structures such as 3 and 6 story buildings the accuracy of the equations varies considerably, depending on earthquake (Fig. 9).

For the structures more flexible, Eqs. 7 to 10 seem to give good approximation. However, at a few earthquakes they produced significant errors (Fig. 9), reducing the accuracy of the SPD-based method. This was seen from the record like Chi Chi (earthquakes 24 to 26), under which the 18 to 24 story buildings showed biased motion, shifting to one side and developing much larger displacement than predicted by the elastic approach.

In order to maintain a reasonably conservative performance for practice, the required separation distance $s_{\mathrm{req}}$ based on $u_{\mathrm{rel}}(\mathrm{SPD})$ should be scaled by a conservative factor $\gamma$ as follows

$$
s_{\text {req }}=\gamma \cdot u_{\text {rel }}(\mathrm{SPD})
$$

here $\gamma=1.2$ to 1.45 for earthquake from moderate $(0.2 \mathrm{~g})$ to catastrophic $(0.8 \mathrm{~g})$ level, and linear interpolation may be applied for other levels.

Statistically, Eq. 16 would give more than $85 \%$ confidence for the $s_{\text {req }}$ to be greater than the 'exact' value obtained from time history analysis. Note that SRSS and ABS methods require much higher $\gamma$ values as well as $u_{\mathrm{rel}}(\mathrm{SRSS})$ and $u_{\mathrm{rel}}(\mathrm{ABS})$, resulting in much larger estimates to achieve the same confidence level.

\section{APPLICATION OF SIMPLIFIED SPD-BASED METHOD}

The previous sections indicated that the peak relative displacement of adjacent inelastic buildings could be approximated by the use of elastic SDOF systems. The writers also performed some numerical experiments using adjacent multi-degree-of-freedom (MDOF) systems, from which the straight-line deformation mode used for the SDOF model is still found to produce good estimate for $u_{\text {rel. }}$. This modeling is not recommended, however, for buildings having very irregular deformed shape (e.g. soft or weak story building), unless such deformation is accounted for in the SDOF model. In spite, practitioners may find the SPD-based method simple and useful for preliminary design, since the method gives them full control over the relative displacement problem.

Making use of attractive features of the SPD-based method, an even simpler version of the method is presented herein. This graph-oriented version will equip users with a handy tool that can help them quickly judge the peak relative displacement between adjacent buildings.

If the building belongs to the constant spectral velocity domain, its peak elastic displacement becomes proportional to initial vibration period. Moreover, since Eq. 8 for such a period range becomes similar to Newmark and Hall's equal displacement rule ${ }^{10}$, elastic displacement is assumed to be the same as inelastic displacement. Based on these,

$$
\frac{u_{\mathrm{A}}}{u_{\mathrm{B}}}=\frac{1.5\left(H_{\mathrm{B}} / H_{\mathrm{A}}\right) \Delta_{\mathrm{A}}}{1.5 \Delta_{\mathrm{B}}}=\frac{H_{\mathrm{B}} / H_{\mathrm{A}}}{T_{\mathrm{B}} / T_{\mathrm{A}}}
$$

Substituting the above relationship into Eq. 4 and by manipulations,

$$
u_{\mathrm{rel}}(\mathrm{SPD})=u_{\mathrm{B}} \sqrt{1+\left(\frac{H_{\mathrm{B}} / H_{\mathrm{A}}}{T_{\mathrm{B}} / T_{\mathrm{A}}}\right)^{2}-2 \rho_{\mathrm{AB}} \frac{H_{\mathrm{B}} / H_{\mathrm{A}}}{T_{\mathrm{B}} / T_{\mathrm{A}}}}
$$

where $u_{\mathrm{B}}=$ peak elastic displacement at the top level of building $\mathrm{B}$. The cross correlation $\rho_{\mathrm{AB}}$ still can be obtained by Eq. 5, using initial periods, damping ratios, and buildings' ductility demands.

From Eq. 12, let's introduce the material type combination factor $\beta_{c}$ as

$$
\beta_{c}=\frac{H_{\mathrm{B}} / H_{\mathrm{A}}}{T_{\mathrm{B}} / T_{\mathrm{A}}}= \begin{cases}1.0 & ; \text { Steel vs. Steel, or Conc. vs. Conc. } \\ 1.50 & ; \text { Steel vs. Conc. } \\ 0.67 & ; \text { Conc. vs. Steel }\end{cases}
$$

Then substituting this $\beta_{c}$ factor into Eq. 18 ,

$$
u_{\mathrm{rel}}(\mathrm{SPD}) / u_{\mathrm{B}}=\sqrt{1+\beta_{c}^{2}-2 \rho_{\mathrm{AB}} \beta_{c}}
$$

Eq. 20 is plotted in Fig. 10 for the buildings having initial damping ratio $2 \%$, ductility demands 1 to 6 , and $H_{\mathrm{B}} / H_{\mathrm{A}}$ of $0.4,0.7$, and 1.0 , respectively. Inappropriate estimates from the SRSS- and ABS-based methods are also shown by the red broken line and solid line, respectively. They appear to be constant with respect to not only ductility demands but also height ratios.

Fig. 10 can be used to quickly estimate the relative displacement $u_{\text {rel }}$. When the values of $H_{\mathrm{B}} / H_{\mathrm{A}}, \mu_{\mathrm{A}}$ and $\mu_{\mathrm{B}}$, and peak elastic displacement $u_{\mathrm{B}}$ are known for a specific problem, a preliminary assessment of the $u_{\mathrm{rel}}$ can be carried out with these graphs.

For small $H_{\mathrm{B}} / H_{\mathrm{A}}$, effect of ductility demand on $u_{\text {rel }}(\mathrm{SPD}) / u_{\mathrm{B}}$ is not very significant (Fig. 10 left). When $H_{\mathrm{B}} / H_{\mathrm{A}}$ increases, $u_{\text {rel }}$ is influenced not only by ductility variation but also on how the material combined.

If $H_{\mathrm{B}} / H_{\mathrm{A}}=1$ and the buildings are made of the same structural material, the graph is symmetric with respect to $\mu_{\mathrm{A}}$ and $\mu_{\mathrm{B}}$. Noticeably, $u_{\text {rel }}=0$ when $\mu_{\mathrm{A}}=\mu_{\mathrm{B}}$, simply because the two buildings become identical hence they must show identical motion at any time. In contrast, a pair with different material combination always give $u_{\text {rel }} \neq 0$ even when $H_{\mathrm{B}} / H_{\mathrm{A}}=1$ and $\mu_{\mathrm{A}}=\mu_{\mathrm{B}}$.

For $H_{\mathrm{B}} / H_{\mathrm{A}}<1$, the graphs are asymmetric and indicate a better outcome in reducing $u_{\text {rel }}$ is obtained by increasing $\mu_{\mathrm{B}}$ rather than $\mu_{\mathrm{A}}$. Since $T_{\mathrm{B}} / T_{\mathrm{A}}<1$, making $\mu_{\mathrm{B}}>\mu_{\mathrm{A}}$ will make $T_{\mathrm{B}}^{*} / T_{\mathrm{A}}^{*}$ closer to 1 (Eq. 6), thereby forcing more in-phase motion (Eq. 5)

\section{CONCLUSIONS}

This paper proposed the new method to estimate seismic peak relative displacement between two inelastic buildings, by combining the writers' spectral difference (SPD) rule and elastic response spectrum. The method is applied to create a unique tool that can be used for preliminary and rapid assessment of the required separation to preclude pounding. They can be used also to find a necessary sliding seat length to prevent falling of a bridge supported by two separate structures.

The conclusions are as follows:

(1) The method is validated through extensive numerical experiments using numerous code-compatible building pairs with different heights and material combinations, as well as 33 earthquakes of 2 directions, scaled to 4 different levels. The method is found to accurate estimate the relative displacement, with a narrow variability of error. As with the appropriate range of $\mu$-value mentioned in Sec. 2.2 and 4.1, this method 

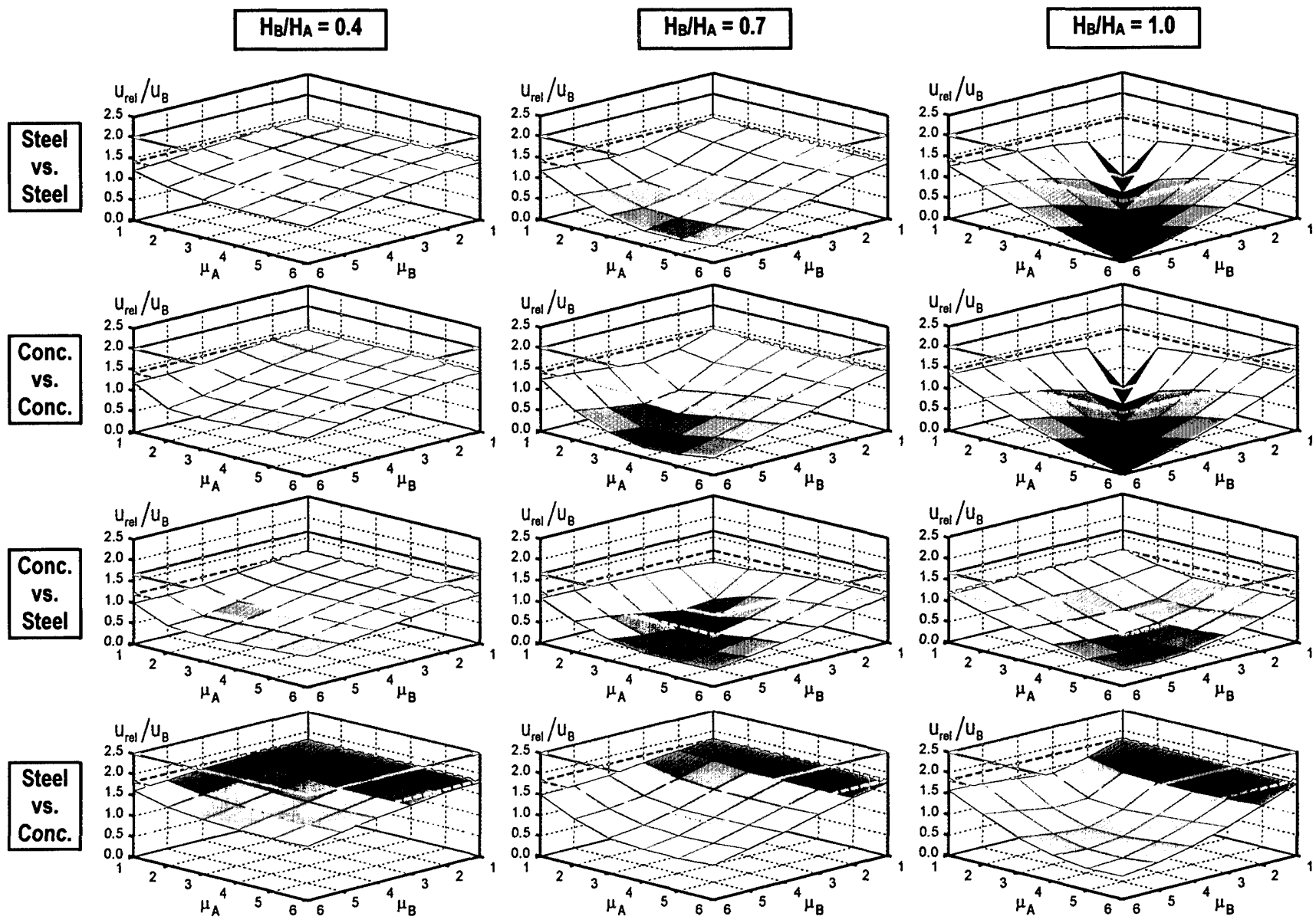

Figure 10. Relative Displacement Normalized by Peak Displacement $\left(u_{B}\right)$ at Top of Building B, Constant Velocity Spectrum Assumed.

is believed to hold for a ductility ratio $\mu$ up to 6 .

(2) Determination of relative displacement requires considerations of many factors such as; building heights, elastic vibration periods, initial yield strengths, hysteretic types, and spectrum characteristics as well as intensities of the earthquakes. Only the SPD-based method explicitly accounts for and clarifies the complex effects of these key parameters, and its use is simple.

(3) The absolute sum (ABS)-based method is excessively conservative for the level of earthquake as well as building stiffness and strength, specified in the current code. The square-root-of-sum-of-square (SRSS)-based method used in the US Code $\mathrm{IBC} 2000^{6}$ gives reasonably conservative estimate for moderate earthquakes, but remains incorrect for strong earthquakes because of not accounting for the relevant effect of hysteretic damping.

More research is motive, especially in consideration of the effects from high supplementary damping, scattering of initial vibration period and yield strength of structure; as well as multi-degree-of-freedom modeling of the buildings with various irregularities.

Lastly, this study assumed no time lag of excitations against adjacent structures. The assumption, which is based on the writers' previous study about effects of seismic travel wave on elastic structures ${ }^{5)}$, follows considerations that buildings' dimensions are not so spacious, their vibration periods are often long enough, and the soil is not too soft. Nevertheless, more in-depth study will be conducted so that the proposed method here for inelastic structures can include effect of travel wave, for covering a wider range of application.

\section{ACKNOWLEDGEMENTS}

The Ministry of Education, Science and Culture provided support for this study in the form of Grants-in-Aid for Scientific Research, Category C (Research Representative: Kazuhiko Kasai), and the second author's Monbu Kagakusho Scholarship. The authors gratefully acknowledge the support. The authors also thank Mr. Jagiasi for his initial participation, and Prof. Motoyui for his valuable suggestions. REFERENCES

1) Bertero, V.V.: Observation of Structural Pounding, Proc., International Conference: the Mexico earthquake-1985, ASCE, NY., 264-278, 1986.

2) Rosenblueth E., and Meli, R. The 1985 Earthquake: Causes and Effects in Mexico City, Concrete Journal, ACI, Vol.8, No. 5, 23-24, 1986.

3) Kasai K. and Maison B.F.: Building Pounding Damage During The 1989 Loma Prieta Earthquake, Engineering Structures, Vol.19, No.3, 195-207, 1997.

4) Kasai K., Jagiasi R.A., and Jeng V.: Inelastic Vibration Phase Theory For Seismic Pounding Mitigation, J. Struct. Eng., ASCE, 122(10), 1136-1147, 1996.

5) Jeng V., Kasai K.: Spectral Relative Motion of Two Structures Due To Seismic Travel Waves, J Struct. Eng.,

ABS SRSS $\approx-\infty$

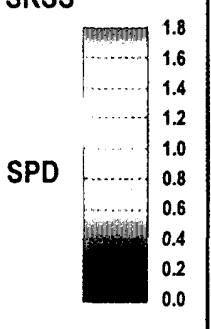
ASCE, 122(10): 1128-1135, 1996

6) IBC 2000: International Building Code, International Code Council, Virginia, 2000.3 .

7) Der Kiureghian A.: A Response Spectrum Method For Random Vibrations, Report No. UCB/EERC-80/15, U. of Calif., Berkeley, 1980.

8) 笠井和彦, 元結正次郎, 大木洋司：水平地票動を受ける空間構造への粘弾性 ダンパーの適用と応答性状に関寸る一考察, 日本建築学会構造系論文集, 561 号, pp125-135, 2002.11.

9) Chopra A.K.: Dynamics of Structures: Theory and Applications to Earthquake Engineering, Prentice-Hall, Inc., New Jersey, 1995.

10) Newmark, N.M. and Hall, W.J.: Seismic Design Criteria for Nuclear Reactor Facilities, Report No.46, Building Practices for Disaster Mitigation, National Bureau of Standards, U.S. Department of Commerce, 1973.

11) Uang C.M.: Seismic Force Reduction and Displacement Factors. Proc. 10th WCEE, Madrid, Spain, 1992.

12) Nassar A.A. and Krawinkler H.: Seismic Demands for SDOF and MDOF Systems The John A. Blume Earthq. Eng. Center, Stanford University, 1991.

13) Miranda E.: Site-Dependent Strength Reduction Factors. J. Struct. Eng., ASCE, 119(12): 3503-3519, 1993.

14) Miranda E.: Evaluation of Strength Reduction Factors for Earthquake Resistant Design. Earthquake Spectra, EERI, 10(2): 357-379, 1994.

15) IAEE: Regulations for Seismic Design, A World List .. 1996 International Association for Earthq. Eng., Tokyo, Japan, 1996.

16) 笠井和彦, 伊藤浩資, 渡辺厚：等価線形化手法による一質点弹塑性跷造の最 大志答予測法, 日本建築学会構造系論文集, 571 号, pp.53-62, 2003.9.

17) Mahin S.A. and Lin J.: Construction of Inelastic Response Spectra for Single Degree of Freedom Systems, Report No. UCB/EERC-83-17, U. of Calif., Berkeley, 1983. 


\section{和文要約}

\section{1 はじめに}

\section{1 相対変位問題}

地震時に隣接建物が異なる摇れ方をすると染刻な衝突被害が起こ り得る (図 1)。また、エキスパンションジョイントや連結橋をもつ建 物でも同様である。衝突回避に必要な建物間隔は、非衝突を前提と した時刻歷解析で両建物間の最大相対変位を求め決定できるが、そ れでは、ある地震入力での特解を得るだけである。一方、忘答スペ クトルを用いる手法があれば、様々な地震や建物の特性の影響を包 括的に捉えて相対変位問題を解明でき、評価も容易になる。

\section{2 目的および全体概要}

Kasai らは、各建物の振動位相を建物周期・減衰の関数として表し、 これと最大変位の值のみから最大相対変位を求める「SPD (スペクト ル差)則」を提案した。しかし、各建物の最大変位の評価は、弾塑性 スペクトルまたは弾塑性時刻歷解析を必要としていた。

本論では、より有用な手法として、SPD 則に弾性スペクトルを併 用した簡易評価法を提案する。日本の規準に則った隣接建物を 2 体 の 1 自由度モデルとして多数作成し、様々に増幅した 33 地震波を用 いて本手法の精度を実証し、スペクトルに基づく他手法とも比べる。 なお本手法は、2 つの構造物が離れるため連結橋が落下するような 問題にも有効で、橋端のローラー支持部長さの決定にも用いられる。

\section{2 相対変位とその様々な評価法}

\section{1 既往評価則}

建物 A, B の衝突が予想される位置 (図 1)でのそれぞれの最大変位 絶対值 $u_{\mathrm{A}}, u_{\mathrm{B}}$ を用い、 $\mathrm{ABS}$ (絶対和)則や $\operatorname{SRSS}(2$ 乗和平方根)則によ り、最大相対変位 $u_{\mathrm{rel}}$ を求める(式 $\left.3 \mathrm{a}, \mathrm{b}\right)$ 。

\section{$2.2 \mathrm{SPD}$ 則}

SPD 則は、 $u_{\mathrm{A}}, u_{\mathrm{B}}$ のほかに両建物間の相関係数 $\rho_{\mathrm{AB}}$ を含む(式 4,5$)$ 。 $\rho_{\mathrm{AB}}$ は建物の周期・減衰定数で陽に表されるが、弾塑性建物では等 価周期・等価減衰を用い、一方それらは初期 (弹性) 周期、初期减 衰、塑性率で表される。また、 $0 \leq \rho_{\mathrm{AB}} \leq 1$ であり、 $\rho_{\mathrm{AB}}$ が大きいほど両 建物の位相が類似することを示し、 $u_{\mathrm{rel}}$ の評価值が小さくなる。両等 価周期が類似する場合や等価減衰が高い場合に $\rho_{\mathrm{AB}}$ が大きい。

\section{3 相対変位と振動位相}

\section{1 相対変位の傾向}

異なる弾性周期をもち隣接する 2 体の 1 自由度系で、1)両者が低 减衰の場合、2)両者が弾塑性で塑性率 3 のため等価减衰が高い場合、 3)両者が弾塑性で短周期、長周期構造それぞれで塑性率 6 と 3 の場 合を考える。応答時刻歷から、位相差や $u_{\mathrm{rel}}$ はこれらの順番に小さ くなる(図 3)。また、時刻歷から得た各構造の最大変位を上記評価則 に代入した場合、SPD 則が $u_{\mathrm{rcl}}$ を正確に予測し、SRSS 則、ABS 則は 相関係数 $\rho_{\mathrm{AB}}$ をそれぞれ一定值 0 と 1 とするため誤差が大きい。

\section{2 振動位相の傾向}

相関係数 $\rho_{\mathrm{AB}}$ と弾性周期、减衰定数、塑性率の関係をプロットし た(図 4)。両建物が弾性だと、弾性周期・減衰定数が両建物でほぼ一 致しない限り $\rho_{\mathrm{AB}}$ が低く、位相がかなり異なる。弾塑性時には塑性 率が高いほど $\rho_{\mathrm{AB}}$ が高くなる。また、特に両建物のうち短周期構造 の塑性率が大きくて等価周期が長周期構造とほぼ等しくなると、 $\rho_{\mathrm{AB}}$ $\approx 1$ ，つまり、位相が酷似する(表 2)。これが、前節 3)が最小の相対変 位を示した理由である。このように、SPD 則によれば、隣接する弾 塑性構造における位相を良好な精度で予測できる。

\section{$4 S P D$ 則に基づく簡易手法}

\section{1 弾性スペクトルによる個々の建物の弾塑性变位予測}

弹性スペクトルから弾塑性構造物の最大応答を予測する手法に 関し、多くの研究がなされてきた。これらから Nassar-Krawinkler 式 (8-10)を採用する。弹性と仮定して求めた最大変位(以後、弾性変位) と構造物の降伏変位の比、つまり強度低減係数を用いて、弾塑性構 造のそれぞれ最大変位(以後、弾塑性変位)を近似的に求める(図 5)。 4. 2 SPD 則に基づく簡易な相対変位評価の手順
両建物の弾性周期、初期减衰定数、降伏変位が既知とする。手順 として、1)両建物の等価高さでの弹性変位を弾性応答スペクトルに より求める。2)同位置における弾塑性変位と塑性率を 4.1 節手法で 求める。3)衝突が予想される高さ位置での両建物相対変位を、直線 変形モードを仮定し幾何学から求める。4)等価周期・减衰定数を求 める。5)相関係数 $\rho_{\mathrm{AB}}$ および最大相対変位 $u_{\mathrm{rel}}$ を SPD 則から求める。 4.3 耐震規準に則った建物モデル

日本の一次設計に則った建物モデルを考える。鉄骨および鉄筋コ ンクリートのラーメン構造 2 種を考虑し、それぞれの弾性周期の規 淮予測式を用いる。また、降伏力も $R_{\mathrm{t}}$ 曲線に基づく規準要求值を満 たす。剛性の要求值は満たされている。

\section{4 簡易手法の適用例}

15 階建てと 12 階建ての鉄骨建物を例にとり、4.2 節の手順を詳細に 示す。これらが、0.4gに基準化された Northridge 地震(Newhall 波)をう けたとして、SPD 則、SRSS 則、ABS 則に基づく簡易手法で、弾性ス ペクトルから $u_{\text {re }}$ 值をそれぞれ評価したところ、やはり SPD 則に基づ くものが格段に高い精度を示した。

\section{5 耐震規準に則った隣接建物の相対変位}

我国のレベル 2 設計荷重を標準として、入力荷重、建物高さ、余 剩耐力係数を変化させ、 $u_{\mathrm{rel}}$ の傾向を図 6 に示す。余剩耐力係数 1 の 場合、 $0.4 \mathrm{~g}$ 以上の大地震レベルでは、両建物高さの比によらず、 $u_{\mathrm{rel}}$ がほぼ一定で、高層側高さ $(60 \mathrm{~m}) 00.006$ 倍となる。余剩耐力係数が より大きいと $u_{\mathrm{rel}}$ が増すが、 2 以下であれば、高層側高さの 0.01 倍 以下である。建物強度が大だと $u_{\mathrm{rel}}$ が増える理由は、塑性化しにく いため等価減衰が少なく、よって両建物の位相が異なるためである。

\section{$5 S P D$ 則に基づく簡易手法の精度検証}

\section{1 検証に用いたパラメータ}

隣接建物の高さ組み合わせ 36 種、鉄骨またはコンクリートの組 み合わせ 4 種からなる計 144 種を考虑する(表 4)。地震波は 33 種、 正負方向の 2 種、最大加速度 $0.2 \mathrm{~g} \sim 0.8 \mathrm{~g}$ の 4 種であり、計 264 種を 考慮する。よって、組み合わせは総計 38,016 となり、これらに対し SPD 則、SRSS 則、ABS 則に基づく簡易手法を適用した。

\section{2 検証結果}

予想通りSPD 則に基づく簡易手法が、誤差平均・バラツキ共に格 段に小さい(図 8)。SRSS 則で 0.2g の地震で同様な精度を得たのは、 特に中長周期建物が概ね弾性であったからである。これ以上の地震 では SRSS, ABS の順に安全側だが、誤差平均・バラツキとも非常に 大きい(表 5)。なお、時刻歴解析では反対 2 方向の地震入力における $u_{\mathrm{rec}}$ を算定し、その最大值で必要建物間隔 $s_{\mathrm{req}}$ を決めることができる が、SPD 則はその平均值を予測する。これと様々な地震での本簡易 手法のバラツキを考虑し、確率 $85 \%$ \%範囲で衝突を防ぐ建物間隔 $s_{\mathrm{req}}$ の簡易式を導いた(式16)。他の確率でも同様に導くことができる。

\section{SPD 則に基づく簡易手法の応用}

中・長周期建物をふまえ速度スペクトル一定を仮定する。この周 期帯で Nassar-Krawinkler 式は Newmark-Hall 変位一定則と類似し、 弾塑性変位と弹性変位が等しいと仮定できる。これを用い、低層側 建物頂部の弾性変位をスペクトルから求め、その割合として弾塑性 の隣接建物の相対変位が簡易に表される(式 20)。これを用い、隣接 建物における相対変位の值や傾向の理解を促寸図 10 も作成できた。

\section{7 結論}

(1) 多数の数値実験により、SPD 則と弾性スペクトルを併用する簡 易手法の精度が統計的に実証された。これによる予測と厳密解 の比の平均値は、ほぼ1であり、標準偏差も低い。

（2）SPD 則に基づく手法のみが、相対変位問題の重要因子(2.2 節) の影響を明確に表すことができ、また、その適用は易しい。

(3) ABS 則に基づく手法は合理的でなく、誤差も大きい。SRSS 則 は、建物履歷减衰が小さい小地震で精度が高いが、大地震時で は大きな誤差をもつ。両者とも誤差傾向が一貫しない。

なお、高い付加減衰、周期・降伏力ばらつき、多質点系の変形モ 一ド、両建物の入力位相差などの影響が、今後の課題である。 